\title{
Content of carbon, nitrogen, oxygen, sulfur and phosphorus in native aquatic and cultured bacteria
}

\author{
Kjell Magne Fagerbakke, Mikal Heldal*, Svein Norland
}

Department of Microbiology, University of Bergen, Jahnebakken 5, N-5020 Bergen, Norway

\begin{abstract}
The content of carbon, nitrogen, oxygen, phosphorus and sulfur was measured in individual cells from 6 native aquatic samples and 4 samples of cultured bacteria by $X$-ray microanalysis using a transmission electron microscope (TEM). The molar C:N:P ratio for the pooled sample was 50:10:1 From length and width measurements of unfixed air-dried cells we estimated cell volumes over a total range of 0.0026 to $15.8 \mu^{3}$, and mean C:volume ratios of 30 to $162 \mathrm{fg}^{-3} \mathrm{~m}^{-3}$ for the samples included. For the marine samples we found mean $\mathrm{N}$ : C ratios of 0.25 to 0.28 , while cells from fresh or brackish waters had mean $\mathrm{N}: \mathrm{C}$ ratios of 0.17 to 0.20 , indicating differences in nutrient availability. The P:C ratios for the samples analyzed varied from 0.040 to 0.090 , with a pooled mean of 0.052 , which is approximately twice that of the Redfield ratio for P:C. For O:C ratios we estimated a pooled mean of 0.37 and a range of 0.22 to 0.77 for all samples. We may conclude that slow-growing or non-growing cells have low $\mathrm{O}: \mathrm{C}$ ratios. The mean $\mathrm{S}: \mathrm{C}$ ratio for all samples was 0.031 , with a range of 0.016 to 0.084 for the sample means. A general conclusion is that single-cell analyses of elemental composition give important information on the physiological conditions of cells and on possible nutrient limitations. The rationale for this is the assumption that changes in macromolecular composition are due to nutrient availability.

KEY WORDS: X-ray microanalysis C Carbon Nitrogen - Oxygen - Sulfur - Phosphorus - Volume Ratios
\end{abstract}

\section{INTRODUCTION}

Bacteria are important participants in the turnover of organic and inorganic material and are also important for production in aquatic environments. In lakes this secondary production may, in terms of carbon, equal primary production (Morris \& Lewis 1992). It has been suggested that the flux of organic $C$ from primary production strongly regulates bacterial production (Cole et al. 1988), but inorganic nutrients like $P$ and $N$ may also contribute to bacterial growth regulation.

Bacterial biomass is commonly estimated through measurements of total cell numbers, bacterial biovolume, and the use of conversion factors for $C$ :volume ratios (Fry 1990 and references therein). C:volume ratios over a broad range have been reported for native aquatic bacteria (Watson et al. 1977. Bratbak 1985, Kogure \& Koike 1987, Lee \& Fuhrman 1987). Furthermore, the $\mathrm{N}: \mathrm{C}$ and $\mathrm{P}: \mathrm{C}$ ratios based on bulk measure-

-Addressee for correspondence.

E-mail:mikal.heldal@im.uib.no ments reported for bacteria also show large variations (Bratbak 1985, Vadstein \& Olsen 1989, Tezuka 1990). Despite the variation, the relative amount of nitrogen and particularly of phosphorus is higher in bacteria than in algae. Goldman et al. (1987) found a molar C:N:P ratio of 45:9:1 for bacteria, whereas the commonly referred to molar Redfield ratio for algae is 106:16:1 (Redfield et al. 1963).

Despite their importance for an understanding of the microbial ecosystem, relatively few studies of the elemental composition of bacteria and of how this composition is influenced by growth conditions have been presented. The elemental composition of bacteria determines the quality of the material that is transported to higher trophic levels by grazing, and it also controls their role in the regeneration process, whether or not they excrete or consume mineral nutrients (Parnas 1975, Goldman et al. 1987, Goldman \& Dennet 1991). The elemental composition of bacteria also reflects the conditions under which they grow and may point to possible limiting factors (Egli 1991). Several studies have shown that the growth rate of microor- 
ganisms is more closely related to the cellular content of a limiting nutrient than to external nutrient concentrations (Droop 1983, Vadstein et al. 1988)

A large discrepancy between total counts and viable counts of bacteria from aquatic environments may indicate that a considerable fraction of the cells are non-growing, dormant or inactive (Hobbie et al. 1977. Fry \& Zia 1982, Zweifel \& Hagström 1995). If this nongrowing or dormant fraction is nutrient limited, measurements of the elemental composition should reveal the limitation to the extent that it is possible to measure structural elements like carbon, nitrogen, and phosphorus at single-cell levels.

Most microbiological methods are based on bulk techniques, which determine a population mean for a measured property. However, with the advent of single-cell techniques, e.g. flow cytometry and quantitative image analysis, the importance of the heterogeneity of cultures has been appreciated, a heterogeneity which goes beyond that caused by binary fission alone. Kell et al. (1991) have shown that cultures of Micrococcus luteus may have a bimodal distribution of autofluorescence. Transmission electron microscopes (TEM) equipped with energy dispersive $X$-ray detectors have been used for quantitative measurements of the elemental composition of single cells (Heldal et al. 1985, Fagerbakke et al. 1991, Norland et al. 1995).

In this study we use a method developed by the authors (Norland et al. 1995) based on X-ray microanalysis (XRMA) in TEM to measure the major structural elements (carbon, nitrogen, oxygen, phosphorus and sulfur) in single bacteria from both cultured and native samples. The objective is to describe the variation of elemental composition within and among samples and to study how nutritional status and growth conditions are reflected in the elemental composition of the cells.

\section{MATERIAL AND METHODS}

Native bacteria were sampled from 4 locations on 6 occasions: Raunefjorden, $15 \mathrm{~km}$ south of Bergen, Norway $\left(60^{\circ} 16^{\prime} \mathrm{N}, 5^{\circ} 14^{\prime} \mathrm{E}\right)$ in June and Octoher 1993: Lake Kalandsvatnet, $10 \mathrm{~km}$ south of Bergen $\left(60^{\circ} 17^{\prime} \mathrm{N}\right.$, $5^{\circ} 25^{\prime} \mathrm{E}$ ) in October 1992; Tvärminne, Finland (59 $51^{\prime}$ N, 23 $16^{\prime} \mathrm{E}$ ) in July 1993; Knebel Vig, Aarhus Bight, Denmark $\left(56^{\circ} 10^{\prime} \mathrm{N}, 10^{\circ} 30^{\prime} \mathrm{E}\right)$ in June 1992 and July 1994.

Samples of laboratory-grown bacteria Escherichia coli and Vibrio natriegens were obtained from both growing cultures and from cultures in the stationary phase. The cultures and samples were prepared as follows
Escherichia coli B6 wildtype was grown in a medium with a low potassium concentration. $\mathrm{NaH}_{2} \mathrm{PO}_{4}$ (4.5 mM), Na $\mathrm{HPO}_{4}(1 \mathrm{mM}), \mathrm{NaNO}_{3}(10 \mathrm{mM}), \mathrm{KCl}$ (1 $\mathrm{mM}), \mathrm{MgSO}_{4}(10 \mathrm{mM})$. The cells were grown in a $100 \mathrm{ml}$ batch culture at $37^{\circ} \mathrm{C}$ on a rotary shaker. After $24 \mathrm{~h}$, in the stationary growth phase, samples for XRMA and CHN (carbon, hydrogen, nitrogen) analysis were taken. The culture was then diluted by adding 2 parts $(70 \mathrm{ml}) 1 \%$ Nutrient Broth (Oxoid) to $30 \mathrm{ml}$ of the culture. Samples from exponentially growing bacteria were taken after $1 \mathrm{~h}$ of incubation.

Vibrio natriegens NCMB857 was grown in BHI (brain heart infusion) medium (Oxoid) ( $37 \mathrm{~g} \mathrm{l}^{-1} \mathrm{BHI}$ was dissolved in $70 \%$ artificial sea water and sterilized). The cells were grown at $35^{\circ} \mathrm{C}$ in a water bath with shaking. Samples were taken in the mid-exponential growth phase $(1 \mathrm{~h})$ and $30 \mathrm{~min}$ after the onset of the stationary phase, i.e. $2 \mathrm{~h}$ after the start of incubation. Growth was mcasured as light absorption at $620 \mathrm{~nm}$ using a spectrophotometer

The bacteria were harvested by centrifugation onto aluminium grids (100 mesh; Agar Scientific, Stansted, Essex, UK) supported with carbon-coated formvar film. Neither fixatives nor stain were applied. The cells were air-dried at ambient conditions and analyzed in a JEOL $100 \mathrm{CX}$ transmission electron microscope operated in scanning mode and equipped with a Tracor ZMAX 30 detector featuring silicon crystal and Norvar single window for light-element detection. The microscope was operated at $80 \mathrm{kV}$, with a magnification between $10000 \times$ and $60000 \times$, and the grids were placed between high-purity carbon plates at a $38^{\circ}$ nominal take-off angle. X-ray spectra were accumulated for $50 \mathrm{~s}$ (live time) in a Tracor multichannel analyzer and stored on floppy disks. The scanned area, bacterial length and width were measured on the CRT (cathode ray tube) screen, which was calibrated with latex beads (Agar Scientific). A particle-free area near each bacterium was chosen for the film background spectrum.

Processing of spectra. The spectra were transformed to MS-DOS-compatible binary files using a laboratory computer (MINC, Digital Equipment Corporation). All software and calibration procedures involved were develnner by the authors, and the principles involved are described by Norland et al. (1995). Volume was determined by assuming the cell to be cylindrical with hemispherical ends. Dry matter was determined as the sum of all measured elements, assuming a hydrogen content equal to $1 / 6$ of the carbon content.

Due to the wide range of cell sizes included in the analyses and to the skewed (approximately log-normal) distribution of the measured properties of the cells, we chose to calculate all means and standard deviations from log-transformed data. These were 
then converted back to the linear domain (antilogs of log-transformed data) for presentation. This implies that all means are geometric, which for this set of data are 10 to $30 \%$ lower than the arithmetic ones. We report the standard deviation of log-transformed data as arithmetic coefficients of variation (CV), an approximation that holds for small values.

For the ratio of 2 parameters, $z$ and $y, x_{i}=z_{i} / y_{1}$. The weighted among-group coefficient of variation $\left(\mathrm{CV}_{\mathrm{A}}\right)$ was computed using:

$$
C V_{\mathrm{A}}=\sqrt{\frac{\sum_{g}\left\{n_{j}\left[\ln \left(\bar{x}_{j}\right)-\ln (\bar{x})\right]^{2}\right\}}{\sum_{g} n_{j}-1}}
$$

where $\bar{x}$ is the grand mean of the pooled population, and $\bar{x}_{j}$ is group mean and $n_{j}$ is the sample size of the group. The weighted within-group coefficient of variation $\left(\mathrm{CV}_{W}\right)$ was calculated using:

$$
C V_{W}=\sqrt{\frac{\sum_{g}\left(n_{j} C V_{j}^{2}\right)}{\sum_{g} n_{j}-1}}
$$

where $\mathrm{CV}_{j}$ is the coefficient of variation of the group. The total relative variance is the squared sum of $C V_{A}$ and $C V_{W}$. In this context we used these formulae to compute $C V_{A}$ and $C V_{W}$ using the 10 samples as groups.

The linear regressions between variables ( $C$ vs volume, and $N, O, P$ and $S$ vs $C$ ) were based on logarithmic transformations, using a type II model (Norland et al. 1987):

$$
\ln (y)=b \ln (x)+a
$$

where $x$ and $y$ are the 2 variables, $a$ is the value of $y$ when $\ln (x)=0$ (i.e. $x=1$ ) and $b$ is the scale coefficient and is equal to unity when the 2 variables are proportional.

\section{RESULTS}

Cellular values of volume, dry matter, and the elements carbon, nitrogen, oxygen, phosphorus and sulfur were measured in 404 single bacteria from 10 different sources, and the sample means are shown in Table 1. Native cells were sampled from 4 different locations covering lake water, brackish water and sea water, and from some of these locations during different seasons, and from cultures of Escherichia coli and Vibrio natriegens at different growth stages. The estimated mean volume of the cells varied over nearly 2 orders of magnitude, from 0.11 to $3.8 \mu^{3}$, while the total range of volumes covered more than 3 orders of magnitude: 0.0026 to $15.8 \mu^{3}$. The laboratory-grown bacteria were the largest. They showed significantly different volumes between the growing and stationary phases. The total range of the per cell dry weight of elements was more than 3 orders of magnitude, from $1.4 \mathrm{fg}$ to $1.9 \mathrm{pg}$.

A plot of carbon versus volume single cells values is shown in Fig. 1. The sample means for $\mathrm{C}$ : volume ratios varied from 32 to $160 \mathrm{fg} \mathrm{C} \mathrm{m}^{-3}$ (Table 2); within the total pooled sample the ratio varied by a factor of 30 ,

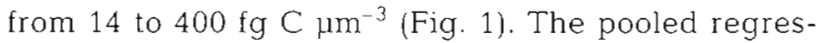

\begin{tabular}{|c|c|c|c|c|c|c|c|c|}
\hline & \multirow{2}{*}{$\begin{array}{l}\text { Volume } \\
\left(\mu \mathrm{m}^{3}\right)\end{array}$} & \multirow{2}{*}{$\begin{array}{l}\text { Dry matter } \\
\text { (fg cell }{ }^{-1} \text { ) }\end{array}$} & \multicolumn{5}{|c|}{ Element content $(\mathrm{fg})$ - } & \multirow{2}{*}{$n$} \\
\hline & & & $\mathrm{C}$ & $\mathrm{N}$ & 0 & $\mathrm{P}$ & $\mathrm{S}$ & \\
\hline \multicolumn{9}{|l|}{ Location, date } \\
\hline Raunefjorden, June 1993 & $0.11 \pm 0.01$ & $21 \pm 2$ & $9 \pm 1$ & $2.2 \pm 0.3$ & $4.0 \pm 0.4$ & $0.50 \pm 0.05$ & $0.43 \pm 0.05$ & 62 \\
\hline Raunefjorden, October 1993 & $0.28 \pm 0.08$ & $37 \pm 8$ & $19 \pm 4$ & $5 \pm 1$ & $5 \pm 1$ & $0.8 \pm 0.2$ & $0.35 \pm 0.09$ & 20 \\
\hline Knebel Vig, Denmark, 1994 & $0.20 \pm 0.02$ & $26 \pm 2$ & $12 \pm 1$ & $2.6 \pm 0.2$ & $4.7 \pm 0.4$ & $0.47 \pm 0.04$ & $0.44 \pm 0.05$ & 95 \\
\hline Knebel Vig, 1992 & $0.21 \pm 0.03$ & $22 \pm 3$ & $7 \pm 1$ & $1.6 \pm 0.2$ & $5.1 \pm 0.7$ & $0.46 \pm 0.07$ & $0.56 \pm 0.07$ & 55 \\
\hline Tvärminne, Finland & $0.31 \pm 0.09$ & $60 \pm 20$ & $31 \pm 10$ & $5 \pm 2$ & $9 \pm 3$ & $1.4 \pm 0.3$ & $0.6 \pm 0.2$ & 17 \\
\hline Lake Kalandsvatnet, Norway & $0.41 \pm 0.03$ & $39 \pm 3$ & $21 \pm 2$ & $4.4 \pm 0.3$ & $4.9 \pm 0.4$ & $1.05 \pm 0.08$ & $0.30 \pm 0.02$ & 87 \\
\hline \multicolumn{9}{|l|}{ Species } \\
\hline \multicolumn{9}{|l|}{ Vibrio natriegens } \\
\hline Growing & $3.5 \pm 0.5$ & $850 \pm 90$ & $350 \pm 40$ & $90 \pm 10$ & $120 \pm 10$ & $17 \pm 2$ & $13 \pm 1$ & 11 \\
\hline Stationary & $0.93 \pm 0.06$ & $145 \pm 5$ & $62 \pm 4$ & $16 \pm 1.0$ & $24 \pm 1$ & $3.4 \pm 0.1$ & $2.5 \pm 0.1$ & 11 \\
\hline \multicolumn{9}{|l|}{ Escherichia coli } \\
\hline Growing & $3.8 \pm 0.4$ & $710 \pm 80$ & $350 \pm 40$ & $100 \pm 10$ & $120 \pm 20$ & $31 \pm 4$ & $9 \pm 1$ & 26 \\
\hline Stationary & $0.7 \pm 0.1$ & $180 \pm 20$ & $110 \pm 10$ & $24 \pm 3$ & $24 \pm 3$ & $6.7 \pm 0.7$ & $1.7 \pm 0.2$ & 20 \\
\hline
\end{tabular}

Table 1 Volumes and element content of bacteria from different locations and cultures. Geometnc means of single cell measurements with standard error. n: number of cells analyzed 


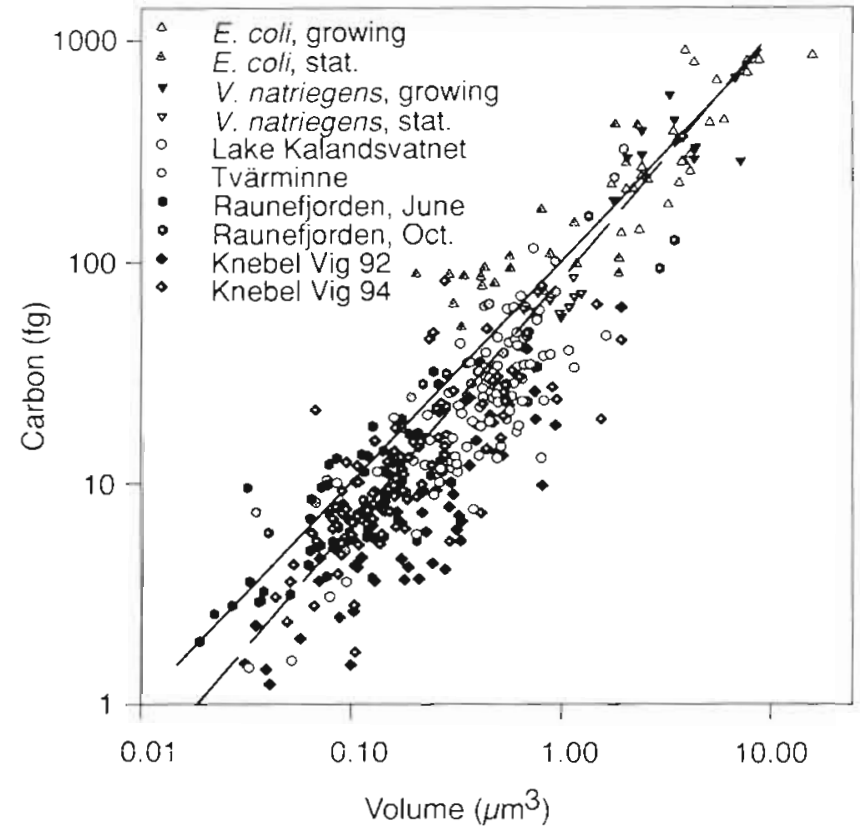

Fig. 1. Log-log plot of carbon content versus cell volumes for

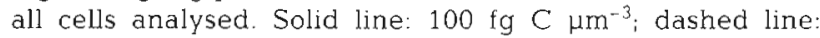
regression line sion of carbon versus volume is expressed in Eq. (4) (Table 3). The regression line (dashed line) from Eq. (4)

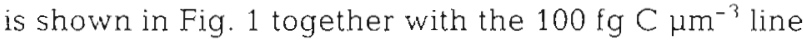
(solid line).

Per cell amounts of nitrogen, oxygen, phosphorus and sulfur content versus carbon are shown in Fig. 2. For all these relationships the regressions lines are drawn from Eqs. (5) to (8), Table 3. In addition, the Redfield ratios for $\mathrm{N}: \mathrm{C}$ and $\mathrm{P}: \mathrm{C}$ are drawn (dashed lines). The mean pooled $\mathrm{N}: \mathrm{C}$ ratio is approximately $30 \%$ higher than the Redfield ratio, while the pooled $P: C$ ratio is nearly 3 times higher than the Redfield ratio. The mean pooled values of $\mathrm{O}: \mathrm{C}$ and $\mathrm{S}: \mathrm{C}$ are 0.37 and 0.031 , respectively.

Elemental ratios of bacteria from the different locations are presented in Table 2. The sample means for the $\mathrm{N}$ : C ratio had values in the range of 0.17 to 0.29 . The marine bacteria had means from 0.22 to 0.26 while the brackish water and freshwater had means from 0.17 to 0.22 . The highest $\mathrm{N}$ : C value, 0.29 , was found for growing Escherichia coli. The highest mean P:C ratio was found for growing $E$. coli and in the bacteria sampled from Knebel Vig in 1992, whilst only small varia-

Table 2. C:volume ratio and ratios of nitrogen, phosphorus, and oxygen relative to carbon (wt:wt) of the samples in Table 1 . Values are given with standard error

\begin{tabular}{|c|c|c|c|c|c|}
\hline & \multirow{2}{*}{$\begin{array}{l}\text { C:volume ratio } \\
\left(\text { fg } C \mu m^{-3}\right)\end{array}$} & \multirow{2}{*}{$N: C$} & \multirow{2}{*}{$\overline{P: C}$ Weig } & \multirow{2}{*}{ a:C } & \multirow[b]{2}{*}{$\mathrm{S}: \mathrm{C}$} \\
\hline & & & & & \\
\hline \multicolumn{6}{|l|}{ Location, date } \\
\hline Raunefjorden, June & $78 \pm 4$ & $0.26 \pm 0.01$ & $0.057 \pm 0.004$ & $0.46 \pm 0.02$ & $0.049 \pm 0.003$ \\
\hline Raunefjorden, October & $67 \pm 7$ & $0.24 \pm 0.01$ & $0.041 \pm 0.005$ & $0.26 \pm 0.02$ & $0.019 \pm 0.003$ \\
\hline Knebel Vig, 1994 & $60 \pm 3$ & $0.22 \pm 0.01$ & $0.040 \pm 0.003$ & $0.40 \pm 0.02$ & $0.037 \pm 0.003$ \\
\hline Knebel Vig, 1992 & $32 \pm 2$ & $0.24 \pm 0.01$ & $0.069 \pm 0.005$ & $0.77 \pm 0.05$ & $0.084 \pm 0.008$ \\
\hline Tvärminne & $103 \pm 9$ & $0.17 \pm 0.02$ & $0.043 \pm 0.007$ & $0.29 \pm 0.03$ & $0.019 \pm 0.003$ \\
\hline Lake Kalandsvatnet & $53 \pm 2$ & $0.20 \pm 0.01$ & $0.049 \pm 0.003$ & $0.23 \pm 0.01$ & $0.016 \pm 0.001$ \\
\hline \multicolumn{6}{|l|}{ Species } \\
\hline \multicolumn{6}{|l|}{ Vibrio natriegens } \\
\hline Growing & $100 \pm 10$ & $0.26 \pm 0.01$ & $0.050 \pm 0.003$ & $0.34 \pm 0.01$ & $0.035 \pm 0.002$ \\
\hline Stationary & $67 \pm 5$ & $0.26 \pm 0.03$ & $0.055 \pm 0.004$ & $0.39 \pm 0.03$ & $0.040 \pm 0.003$ \\
\hline \multicolumn{6}{|l|}{ Escherichia coli } \\
\hline Growing & $92 \pm 6$ & $0.29 \pm 0.01$ & $0.090 \pm 0.005$ & $0.35 \pm 0.02$ & $0.026 \pm 0.003$ \\
\hline Stationary & $160 \pm 20$ & $0.22 \pm 0.01$ & $0.062 \pm 0.002$ & $0.22 \pm 0.01$ & $0.016 \pm 0.001$ \\
\hline
\end{tabular}

Tdivie 3. Regression equations between combinations of varables and the contribution to the total variation of their ratios from within-group variation and among-group variation. Volume (Vl) has the unit $\mathrm{\mu m}^{3}$, all elements given in $\mathrm{fg}$

\begin{tabular}{|c|c|c|c|c|}
\hline \multirow[t]{2}{*}{ Relation } & \multirow[t]{2}{*}{ Regression equation } & \multicolumn{2}{|c|}{ Coefficient of variation } & \multirow[t]{2}{*}{ Eq. no } \\
\hline & & Within $\left(C V_{w}\right)$ & Among $\left(C V_{A}\right)$ & \\
\hline C vs Volume & $\ln (C)=(1.12 \pm 0.03) \times \ln (V !)+(4.28 \pm 0.04)$ & 0.46 & 0.38 & (4) \\
\hline $\mathrm{N}$ vs $\mathrm{C}$ & $\ln (\mathrm{N})=(1.02 \pm 0.02) \times \ln (\mathrm{C})-(1.54 \pm 0.05)$ & 0.42 & 0.12 & (5) \\
\hline P vs C & $\ln (P)=(1.05 \pm 0.02) \times \ln (C)-(3.10 \pm 0.07)$ & 0.53 & 0.24 & (6) \\
\hline Ovs $\mathrm{C}$ & $\ln (0)=(0.94 \pm 0.03) \times \ln (C)-(0.8 \pm 0.1)$ & 0.37 & 0.39 & $(7)$ \\
\hline $\mathrm{S}$ vs $\mathrm{C}$ & $\ln (S)=(1.00 \pm 0.02) \times \ln (C)-(3.5 \pm 0.1)$ & 0.60 & 0.61 & (8) \\
\hline
\end{tabular}




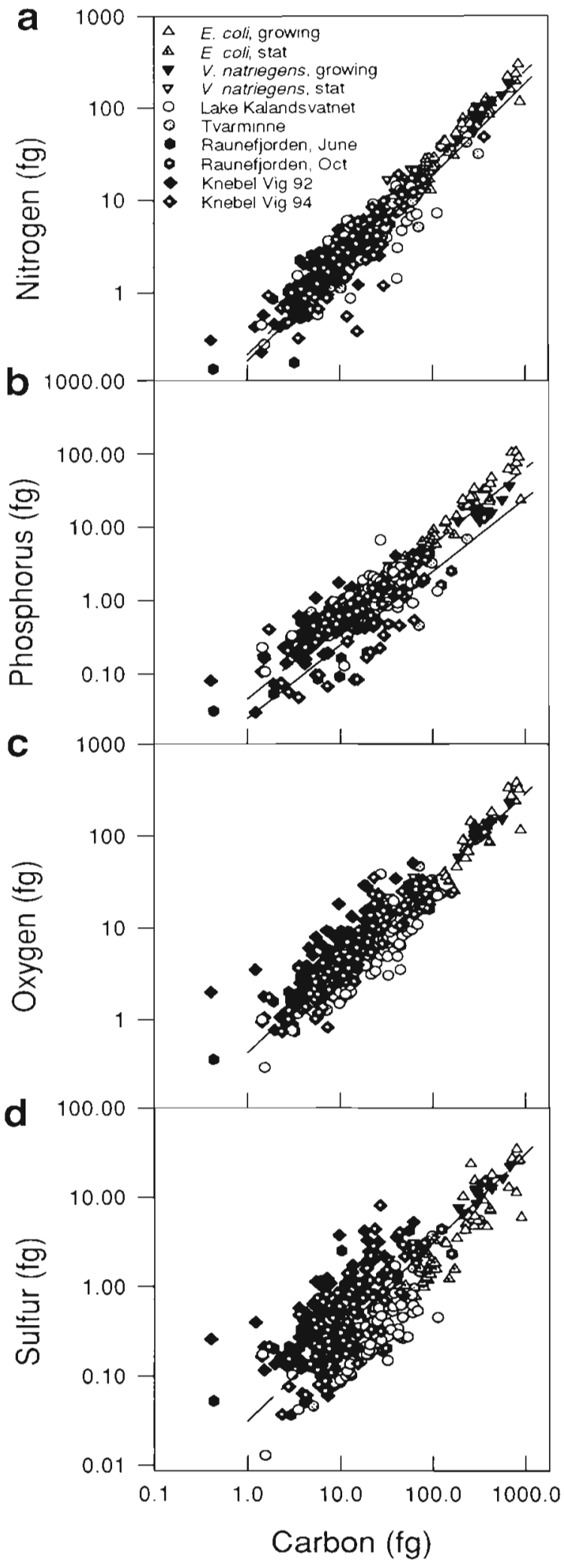

Fig. 2. Log-log plot of nitrogen, phosphorus, oxygen and sulfur versus carbon for all cells analysed. Solid lines: Redfield ratios (nitrogen and phosphorus); dashed lines: regression lines

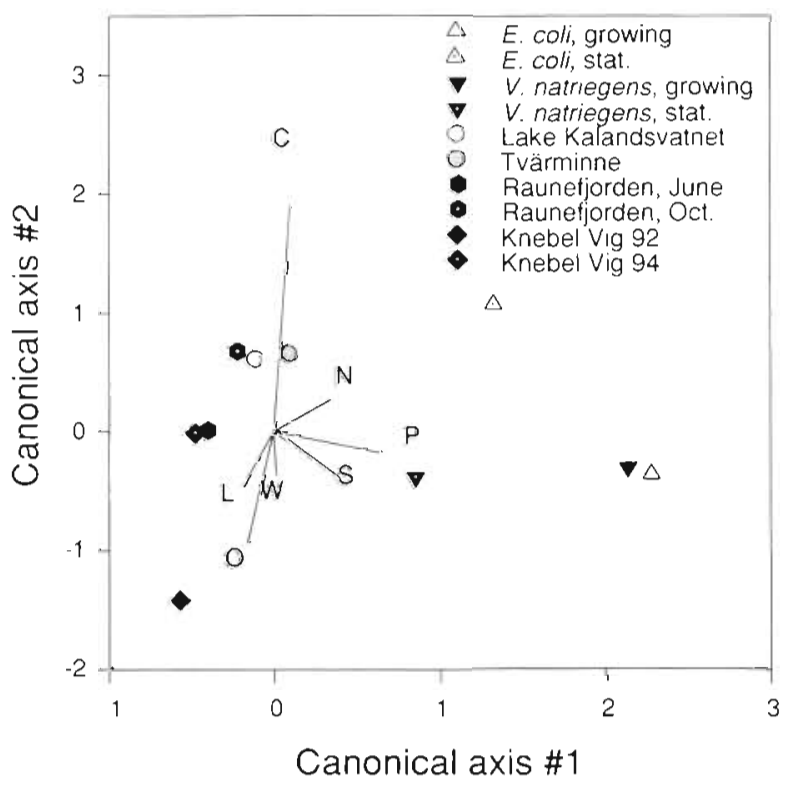

Fig. 3. Canonical variate plot of the first 2 canonical axes (first and second axes explain 45 and $30 \%$ of the total dispersion, respectively). L: bacterial length; $W$ : bacterial width; $\mathrm{C}, \mathrm{N}, \mathrm{O}$, $\mathrm{P}$ and $\mathrm{S}$ are the elements included

tions were determined among the other means. The pooled regressions between nitrogen, phosphorus, oxygen and sulfur versus carbon are given by Eqs. (2) to (5), Table 3, together with corresponding coefficients of variations within and among groups.

Fig. 3 shows a bivariate plot of the first 2 axes from canonical variate analysis using the 10 samples as groups. The 2 axes shown represent $45 \%$ (Axis 1 ) and $30 \%$ (Axis 2) of the total dispersion. The lengths and directions of the original axes indicate the contribution from each parameter to the dispersion of the cells. For Axis $1 \mathrm{P}, \mathrm{S}$ and $\mathrm{N}$ versus cell length $(L)$, and $\mathrm{O}$ are the main contributors, while the contrast between $\mathrm{C}$ and $\mathrm{N}$ versus $O, L, \mathrm{~S}$ and cell width $(W)$ contribute most to the dispersion of Axis 2 .

\section{DISCUSSION}

\section{Cell volume}

The mean cell volumes for bacteria from the native samples varied from 0.11 to $0.41 \mathrm{\mu m}^{3}$. Laboratorygrown Escherichia coli and Vibrio natriegens had mean cell volumes of 3.8 and $3.5 \mu \mathrm{m}^{3}$ during growth and 0.7 and $0.4 \mu \mathrm{m}^{3}$ during the stationary phase, respectively. We estimated cell volumes from measurements of lengths and widths at high magnification $(10000 \times$ to $60000 \times$ enlargements $)$ on air-dried but unfixed and unstained cells. In TEM the contrast is 
usually sufficient to define edges for unstained bacteria, but the edges may be blurred at the highest magnifications The linear dimensions are generally determined with a precision better than $5 \%$, giving an error less than $15 \%$ on volume. From comparative studies where lengths and widths of $E$. coli were measured on living cells (on a wet agar surface, light microscopy) and on air-dried cells (using TEM), we observed that, due to shrinkage, air-dried cells had a volume $10 \%$ less than the living cells (authors' unpubl. results). A more marked shrinkage, about a $40 \%$ reduction of volume, was observed for cells fixed ( $2 \%$ formaldehyde or $1.5 \%$ glutaraldehyde) before air-drying. During drying the cells collapse towards the formvar film due to evaporation of water, which has a high surface tension. Measurements of heights and widths of bacteria using an atomic force microscope (AFM) (Nano Scope III, Digital Instruments, Breda, The Netherlands), showed thal air-dried cells from Raunefjorden (June 1993), harvested by centrifugation onto mica sheets, had a mean height:width ratio of $0.18 \pm 0.06$. The cross-section profiles of the cells were nearly rectangular, and apparently the cells collapsed towards the surface without a notable change in their width (G. Bratbak \& M. Heldal unpubl. results).

Cell volumes were calculated assuming a model consisting of a cylinder with hemispherical ends (Heldal et al. 1985, Nagata 1986). Volume estimates will depend on the model chosen, e.g. assuming an ellipsoidal shape will give a $29 \%$ lower volume at a width:length ratio of 2 . More emphasis should be placed on volume estimates and the models should be made more adaptive so that the volume of a wider range of the bacterial shapes actually found in nature can be better determined. In this context, image analysis should prove to be an important tool.

\section{Dry matter}

In this study the dry weight of cells was calculated as the sum of all measurable elements plus an additional contribution from hydrogen assumed to be $1 / 6$ (wt: wt) of carbon (Norland et al. 1995). As shown in Table 1, the total range of mean dry weights for all samples was between 21 and $850 \mathrm{fg} \mathrm{cell}^{-1}$. In the growing cultures, the per cell dry matter content was 1 order of magnitude higher than the dry matter content in native bacteria. The lower part of the size range was made up by very small bacteria. A subpopulation of the 9 smallest bacteria, in terms of dry weight, was treated separately. This subpopulation, which was comprised of bacteria from 4 different samples, had a mean dry weight of $4 \mathrm{fg}, 1.5 \mathrm{fg}$ carbon and a mean volume of $0.04 \mu^{3}$ Their mean N:C and P:C ratios were not sig- nificantly different from the means of the pooled sample $(0.28$ and 0.09 , respectively). If we assume that all phosphorus in each of these cells $(0.1 \mathrm{fg})$ was associated with DNA, an amount of $1.2 \mathrm{fg}$ DNA cell ${ }^{-1}$ may be estimated. Most of the phosphorus is bound to the nucleic acid fraction (DNA and RNA). RNA:DNA ratios of cells will vary with growth rates and have been reported to be in the range of 1 to 10 (Skjold et al. 1973, Kato 1994). Therefore, a more realistic estimate for the DNA content would be less than $0.6 \mathrm{fg}$ (genome size of $<1000 \mathrm{~kb}$ ). The weight of 1 Escherichia coli genome $(9200 \mathrm{~kb}$, or $-0.5 \mathrm{fg} \mathrm{P})$ is $6 \mathrm{fg}$. Genome sizes of 1.5 to $2 \mathrm{fg}(\sim 0.15 \mathrm{fg} P)$ for native soil bacteria have been reported by Bakken \& Olsen (1991). Similar sizes of bacteria have been reported previously by Psenner \& Sommaruga (1992). Schut et al. (1993) isolated an ultramicrobacterium with a cell volume of $0.06 \mathrm{\mu m}^{3}$ and a DNA content of 1 to $1.5 \mathrm{fg}(\sim 0.1 \mathrm{fg} P)$, but in contrast to Moyer \& Morita (1989) it was concluded that these small cells were actively growing.

The C:dry matter ratio of native marine bacteria was generally lower than that for native freshwater bacteria due to a higher content of inorganic ions $\left(\mathrm{Mg}^{2+}, \mathrm{Cl}^{-}\right.$, $\mathrm{Na}^{+}, \mathrm{K}^{+}$) in the marine bacteria (authors' unpubl. results). We found mean C:dry matter ratios in the range of 30 to $60 \%$ for the various samples; however, $C$ :dry weight ratios as low as $10 \%$ have been reported (Fry 1990).

\section{Carbon-to-volume ratio}

Mean C:volume ratios for the samples ranged from 32 to $160 \mathrm{fg} \mathrm{m}^{-3}$ (Table 2). The lowest of these values is 1 order of magnitude lower than the values commonly used for conversion between volume and carbon (Table 4). The mean $\mathrm{C}$ :volume ratio for the pooled set of data (Fig 1) was estimated to be $63 \mathrm{fg} \mathrm{C} \mu \mathrm{m}^{-3}$ which is also a value at the lower end of the C:volume ratios given in the literature (Table 4; Fry 1990). For the cultured bacteria, the C:volume values (Table 2) were in the same range as those determined earlier by use of the X-ray TEM method (Heldal et al. 1985, Nissen et al. 1987, Norland et al. 1987, 1995), and values determined by Watson et al. (1977).

The highest C:volume ratio in native bacteria, $103 \mathrm{fg}$ C $\mu \mathrm{m}^{-3}$, was found in the sample from Tvärminne. Growth conditions may influence the C:volume ratio, as seen for cells in the growing and stationary phases of Escherichia coli and Vibrio natriegens. For E. coli, the C:volume ratio for stationary phase cells $(160 \mathrm{fg} C$ $\mu^{-3}$ ) was nearly twice that of growing cells $(92 \mathrm{fg} \mathrm{C}$ $\left.\mu \mathrm{m}^{-3}\right)$. The reverse situation was found for $V$.

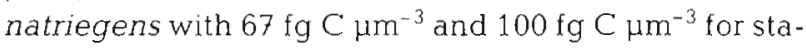
tionary phase and growing cells, respectively. 
The low C:volume ratio of the sample from Knebel Vig (1992) may be explained by the relatively high content of inorganic ions in these cells $(25 \% \mathrm{wt}$ wt; data not shown).

If we assume that the dry matter of bacteria living in water has a specific density of $1.2 \mathrm{pg} \mu^{-3}$ and that carbon makes up $40 \%$ of this dry matter (Table 1), we may calculate a water content of $84 \%$ for the sample from Raunefjorden in June which has a C:volume ratio of

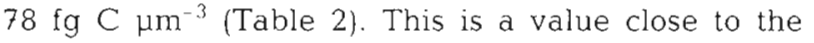
shrinkage seen in AFM for the same sample (see 'Discussion: Cell volume' above). Most of the interest in the relation between carbon and volume stems from the need for a factor to convert biovolume into carbon. In fact, volume-to-carbon conversion enters the calculations in most of the work done involving microbial pools and rates. From the variation among means in C:volume ratio shown in Table 2 it is obvious that a 'universal' conversion factor cannot be used without the risk of introducing an error into one's estimates. The C:volume ratio is directly related to the water content of the bacteria, which in turn depends on the osmotic conditions in the cell. Thus, we think it is reasonable to assume that the $\mathrm{C}$ :volume ratio may vary over a fairly wide range.

The pooled set of data for carbon versus volume is presented in Fig. 1; the dashed line shows the regres-

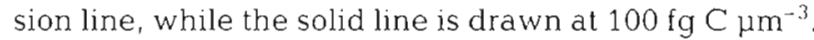
The scale coefficient of the regression equation (Eq. 4, Table 3) is significantly higher than 1, which means that the C:volume ratio is lower for the small bacteria than for the larger ones. This result apparently contradicts previous related studies (Lee \& Fuhrman 1987. Norland et al. 1987, Psenner 1990). It should, however, be noted that the among-sample variation for C:volume ratios is high ( $\mathrm{CV}=0.38$; Table 3 ), and the number of samples is low. The CV for the pooled sample was $59 \%$.

\section{Nitrogen content}

The mean values for nitrogen content in native bacteria were found to range from 1.6 to $5 \mathrm{fg} \mathrm{cell}^{-1}$ (Table 1). The pooled mean N:C value is 0.23 (molar $C: N=5: 1$ ), which is consistent with values reported previously (Nagata 1986, Goldman et al. 1987). As seen from Table 2 , the marine bacteria had similar $\mathrm{N}$ : $\mathrm{C}$ ratios, around 0.24 , which is close to the value of 0.27 reported by Lee \& Fuhrman (1987). However, N:C values of bacteria from marine environments have been reported to vary considerably and within a range from 0.07 to 0.35 (see Table 4 for further references). Assemblages of marine bacteria, grown in batch cultures on

Table 4. C:volume ratios and relative content of nitrogen, phosphorus, and sulfur (wt:wt) in bacteria. Data from the literature. M: marine; B: estuarine/brackish; F: freshwater; S: soil; f: formaldehyde; g: glutaraldehyde

\begin{tabular}{|c|c|c|c|c|c|c|c|}
\hline Bacteria analyzed & Habitat & Fixative & $\mathrm{fg} C \mu \mathrm{m}^{-3}$ & $\mathrm{~N}: \mathrm{C}$ & $P: C$ & $\mathrm{~S}: \mathrm{C}$ & Source \\
\hline Native & $B, F$ & $1 \% \mathrm{f}$ & 350 & & & & Bjornsen (1986) \\
\hline Native & $F$ & $2 \% \mathrm{f}$ & 154 & & & & Scavia \& Laird (1987) \\
\hline Escherichia coll & $F$ & $0.1 \% \mathrm{~g}$ & $126-132$ & & & & Watson et al. (1977) \\
\hline P. putida, E. coli, B. subtilus & $M, F$ & No & $160-290$ & & & & Bratbak \& Dundas (1984) \\
\hline Enriched native & $\mathrm{M}$ & No & $133-400$ & & & & Simon \& Azam (1989) \\
\hline Native & B, M & $2 \% \mathrm{f}$ & $210-1610$ & $0.11-0.41$ & & & Kroer (1994) \\
\hline Enriched native and native & M & $2 \% \mathrm{f}$ & $83-372$ & $0.08-0.29$ & & & Kogure \& Koike (1987) \\
\hline Alkaligens, Pseudomonas & M & No & $155-292$ & $0.17-0.35$ & & & Kogure \& Koike (1987) \\
\hline Native & $\mathrm{F}$ & No & $39-188$ & $0.14-0.30$ & & & Nagata (1986) \\
\hline Native & M & $5 \% \mathrm{f}$ & 280 & 0.27 & & & Lee \& Fuhrman (1987) \\
\hline Enriched native & $\mathrm{F}$ & $1 \% \mathrm{f}$ & $150-170$ & $0.11-0.21$ & $0.017-0.040$ & & Vadstein \& Olsen (1989) \\
\hline Enriched native and $P$. putida & B & $5 \% \mathrm{~g}$ & 560 & $0.15-0.22$ & $0.005-0.16$ & & Bratbak (1985) \\
\hline A. globiformis and E. aerogenes & $\mathrm{S}$ & No & $210-580$ & $0.19-0.30$ & $0.024-0.056$ & & van Veen \& Paul (1979) \\
\hline Enriched native & M & $1 \% \mathrm{~g}$ & & $0.13-0.28$ & $0.020-0.065$ & & Goldman et al (1987) \\
\hline Cultured, unidentified & $\mathrm{F}$ & No & & $0.13-0.21$ & $0.013-0.046$ & & Vadstein (1995) \\
\hline Enriched native & M & No & & $0.07-0.26$ & $0.006-0.083$ & & Tezuka $(1990)$ \\
\hline P. putida & $M$ & No & & $0.15-0.26$ & $0.016-0.074$ & & Martinussen (1991) \\
\hline Cultured, unidentified & $\mathrm{F}$ & No & & 0.25 & & & Finlay \& Uhlig (1981) \\
\hline E. coli & $\mathrm{F}$ & No & 90 & & 0.105 & & Heldal et al. (1985) \\
\hline Enriched native & $\mathrm{F}$ & No & & & $0.027-0.076$ & & Jürgens \& Güde (1990) \\
\hline Enriched native & M & No & $64-136^{\text {a }}$ & $0.15-0.30$ & $0.037-0.067$ & & Tuomi et al. (1995) \\
\hline $\begin{array}{l}P . \text { halodurans, } A \text {. luteo-violaceus } \\
\text { C. lividum } P \text { fluorescens }\end{array}$ & IS M & No & & $0.22-0.33$ & & $0.010-0.011$ & Cuhel et al (1981) \\
\hline and cultured native & $\mathrm{F}$ & No & & & & $0.004-0.012$ & Jordan \& Peterson (1978) \\
\hline
\end{tabular}


substrates with a range of $\mathrm{N}: \mathrm{C}$ values $(0.12$ to 0.78$)$, yielded in the stationary phase cellular $\mathrm{N}: \mathrm{C}$ values in the range 0.19 to 0.28 (Goldman et al. 1987). GräzerLampart et al. (1986), who supplied chemostat cultures of Hyphomicrobium with a range of reservoir N:C values $(0.05$ to 0.78$)$, found that when free $N$ could be detected (reservoir $\mathrm{N}: \mathrm{C}$ higher than ca 0.17 ) the biomass $\mathrm{N}$ : C was approximately 0.29 , whereas when free $C$ was available in the medium (reservoir $\mathrm{N}$ : C less than ca 0.09 ) the biomass $\mathrm{N}: \mathrm{C}$ was approximately 0.19 . Intermediate biomass $\mathrm{N}: \mathrm{C}$ values were found when both $\mathrm{N}$ and $\mathrm{C}$ sources were depleted from the medium.

Lower $\mathrm{N}: \mathrm{C}$ ratios were determined for the bacteria from brackish and fresh waters (Table 2); 0.17 (Tvärminne) and 0.20 to 0.22 (Lake Kalandsvatnet and Escherichia coli, stationary phase). Zweifel et al. (1993) found a N:C ratio of 0.22 for bacteria from the Baltic Sea, an area in which it has been suggested that bacterial growth may be limited by nitrogen (Lignell et al. 1992). A higher $\mathrm{N}$ : C value (0.29) was found for growing cells of $E$. coli (Table 2)

Nitrogen is predominantly associated with protein and nucleic acids, with $N$ : $C$ values of 0.32 and 0.46 , respectively (Norland et al. 1995). Cellular N:C values much higher than 0.35 should, therefore, be difficult to envisage. Cells grown under conditions which allow storage of carbon may have low $\mathrm{N}: \mathrm{C}$ and $\mathrm{P}: \mathrm{C}$ ratios. Conversely, high $\mathrm{N}: \mathrm{C}$ and $\mathrm{P}: \mathrm{C}$ ratios may indicate carbon limitation. Maaloe \& Kjeldgaard (1966) have shown that RNA and protein content of bacteria increase with increasing growth rate. The differences found in N:C and P:C values between stationary and growing Escherichia coli (Table 2) support such a dependency, whereas the data for Vibrio natriegens do not.

The pooled set of data for nitrogen versus carbon content measured at the single-cell level is shown in Fig. 2a, where the dashed line is the regression line and the solid line indicates the Redfield ratio. Table 3 shows the Type II regression equation (Eq. 5) for nitrogen versus carbon based on log-transformed variables. The scale coefficient of Eq. 5 is not significantly different from unity, implying that no size dependence for $\mathrm{N}: \mathrm{C}$ exists in our data. The pooled coefficient of variation of tho N!C value is 0.44 .

\section{Phosphorus-to-carbon ratio}

The mean phosphorus content of the bacteria from the samples varied from 0.47 to $31 \mathrm{fg}$ cell ${ }^{-1}$ (Table 1). The $\mathrm{P}: \mathrm{C}$ ratios for the various samples are given in Table 2 and vary from 0.040 to 0.090 , with a pooled mean value for all samples of 0.052 (molar $C: P=50: 1$ ), which is approximately twice the ratio for P:C given by
Redfield et al. (1963) for algae. From the data presented we find that a 'typical' molar $\mathrm{C}: \mathrm{N}$ :P for bacteria is $50: 10: 1$, a value similar to that found by Goldman et. al. (1987), i.e. 45:9:1. If all phosphorus in the cells were associated with nucleic acids, the mass fraction of nucleic acid in a typical bacterium would be $20 \%$ Excess phosphorus in bacteria is commonly stored as polyphosphate, but despite the fact that polyphosphate granules are easily seen in unstained bacteria in TEM (Kjeldstad et al. 1991), such granules were rarely observed in the samples included.

In Fig. 2b, phosphorus values are plotted versus carbon for the pooled sample. The dashed line in Fig. $2 b$ shows the regression line for the logarithmically transformed data, while the solid line is the Redfield ratio. A Type II regression equation for $P$ versus $C$ is given in Table 3 as Eq. (6). The scale factor indicates that the largest bacteria have a higher P:C ratio than the smaller ones. The coefficient of variation of the $P: C$ ratio for the pooled samples is 0.58 .

\section{Oxygen-to-carbon ratio}

The mean oxygen content of the native bacteria varied in the range of 4 to $9 \mathrm{fg} \mathrm{cell}^{-1}$ for the samples included. The mean per cell values for both Vibrio natriegens and Escherichia coli dropped from $120 \mathrm{fg}$ $\mathrm{cell}^{-1}$ in the growth phase to $24 \mathrm{fg} \mathrm{cell}^{-1}$ in the stationary phase. In Table 2 the mean $\mathrm{O}: \mathrm{C}$ ratios are listed. For the native bacteria these ratios were in the range from 0.23 (Lake Kalandsvatnet) to 0.77 (Knebel Vig, 1992), with a pooled mean for the all samples of 0.37 . Generally, this $\mathrm{O}: \mathrm{C}$ ratio is too low to be explained within the limits of the accepted composition of the bacterial cell; the $\mathrm{O}: \mathrm{C}$ of protein is 0.44 and is even higher for nucleic acids and carbohydrates. The discrepancy is probably due to loss of oxygen during analysis (Norland et al. 1995). For $E$. coli we found a marked reduction of the $0: C$ ratio from 0.35 for cells in the growth phase to 0.22 for cells in the stationary phase. In contrast, there was a slight increase in the $0: C$ ratios from 0.34 for cells in the growth phase to 0.39 for cells in the stationary phase for $V$. natriegens. However. lower $\mathrm{O}: \mathrm{C}$ values in the stationary phase are also found for other cultured bacteria and seem to be a general phenomenon (authors' unpubl. results). The lower $\mathrm{O}: \mathrm{C}$ ratio of cells in the stationary phase may only partly be explained by their lower levels of phosphorus and sulfur. Similarly, the high $\mathrm{O}: \mathrm{C}$ ratio found for the sample from Knebel Vig in 1992 (0.77) can partly be explained by high $\mathrm{P}: \mathrm{C}$ and $\mathrm{S}: \mathrm{C}$ ratios in this sample.

Data for the single cell measurements of oxygen versus carbon (Fig. 2c) are summarized in the equation for 
the Type 2 regression of the $\mathrm{O}: \mathrm{C}$ relationship (Table 3 , Eq. 7). The scale factor of 0.94 suggests that the $O: C$ ratios are higher in small bacteria than in larger ones. One possible explanation for the low oxygen content found in some of these samples may be mass loss of oxygen under the electron beam (Norland et al. 1995). However, since this loss is expected to be dose-dependent, a greater loss should be expected in small bacteria.

The oxygen content of bacteria will give a measure of the oxidation level of the cells. The oxygen fraction of protein, carbohydrates, fats, nucleic acids and polyphosphates are roughly $0.22,0.53,0.08,0.31$, and 0.61 . respectively (Norland et al. 1995). One of the major intracellular reserve polymers is glycogen, a carbohydrate which may be accumulated in the cells during the stationary phase or under nutrient-limited growth conditions with an excess of carbon sources in the media (Preiss \& Romeo 1989). Carbon limitation will most probably lead to a reduced cellular level of carbohydrates (glycogen), fats, nucleic acids (RNA), and protein in this order (Preiss \& Romeo 1989 and references therein). The oxygen content of microorganisms is rarely reported in the literature. Luria (1960) reported a mass fraction of 0.2 , estimated by difference

Based on the results presented, we suggest that the $\mathrm{O}: \mathrm{C}$ ratios of cells may be a signature for the physiological conditions of these cells.

\section{Sulfur-to-carbon ratio}

The mean sulfur content for the samples of native bacteria was in the range from 0.30 to $0.56 \mathrm{fg} \mathrm{cell}^{-1}$. For Vibrio natriegens and Escherichia coli 13 and $9 \mathrm{fg} \mathrm{cell}^{-1}$ and 2.5 and $1.7 \mathrm{fg} \mathrm{cell}^{-1}$ were found for growing cells and cells in the stationary phase, respectively (Table 1). The mean $\mathrm{S}$ : C ratio for pooled set of data is 0.031 , with sample means ranging from 0.016 to $0.084 \mathrm{fg} \mathrm{cell}^{-1}$ (Table 2). The high $\mathrm{CV}$ for the pooled sample is to some extent due to measurement errors caused by the low level of sulfur in the bacteria. The amounts of sulfur measured were close to the detection limit for the method used, and for about $6 \%$ of the cells sulfur was below the detection limit. $\mathrm{S}$ : $\mathrm{C}$ ratios in the range of 0.004 to 0.012 have been reported by others (Jordan \& Peterson 1978, Cuhel et al 1981). Cellular protein may contribute to the cellular $\mathrm{S}: \mathrm{C}$ ratio in the range 0.005 to 0.015 (Jordan \& Peterson 1978, Simon \& Azam 1989). The high S:C ratio of 0.084 found in the bacteria from Knebel Vig in 1992 may partly be explained by a high cellular content of sulfate, since these cells also showed a high $\mathrm{O}: \mathrm{C}$ ratio $(0.77)$. Furthermore, a high correlation is found between $\mathrm{O}: \mathrm{C}$ and $\mathrm{S}: \mathrm{C}$ values; $\mathrm{r}=0.81$ for the pooled sample (data not shown), suggesting that sulfur is associated with oxygen, e.g. as sulfate.

The high sulfur content in marine bacteria could be related to uptake of the compatible solute dimethylsulfoniopropionate (DMSP). DMSP is known to be produced by some algae and are metabolized by bacteria (Kiene 1990, Kiene \& Bates 1990, Ledyard et al. 1993). Two of the samples, Knebel Vig (1992) and Raunefjorden (June 1993), were taken during blooms of Prorocentrum minimum (Prorocentraceae) and Emiliania huxleyi (Prymnesiophyceae), respectively, and both these algae are known to produce DMSP (Matrai \& Keller 1994). If similar DMSP concentrations as determined in E. huxleyi (Malin et al. 1993) occur in marine bacteria, DMSP may contribute up to 0.03 to the bacterial S:C ratio.

For Escherichia coli, values of $<15 \mathrm{mM}$ cytoplasmic dissolved sulfur were found in cells grown at a salt concentration of $0.5 \mathrm{M} \mathrm{NaCl}$ (Cayley et al. 1991). This sulfur content can at the most account for -0.005 of the $\mathrm{S}: \mathrm{C}$ ratio. However, the ratio we have determined (0.026) for growing $E$. coll is higher than the sum of the 2 sulfur fractions based on the data from the literature. In addition, low molecular thiols may participate; however, only low values $(<5 \mathrm{mM}$ ) have been reported (Smirnova \& Oktyabrsky 1995) and may explain approximately 0.001 of the $\mathrm{S}: \mathrm{C}$ ratio.

\section{Sources of variation}

\section{Among-group variance}

For each of the ratios presented in Table 2, the among-samples coefficient of variation, $\mathrm{CV}_{\mathrm{A}}$, was calculated using Eq. (1), and the values are given in Table 3. The lowest $\mathrm{CV}_{\mathrm{A}}$ is found for $\mathrm{N}: \mathrm{C}(0.12)$, a value substantially lower than the variation seen in the literature data (Table 4). Nitrogen is mainly associated with protein and nucleic acids, macromolecules which make up a large fraction of the cellular material, and this will put constraints on the variability of the $\mathrm{N}: \mathrm{C}$ value. The $C_{A}$ is also low for P:C (0.24). The large difference in relative variation between $\mathrm{S}: \mathrm{C}$, which has the highest $C V_{A}(0.61)$, and $\mathrm{N}$ :C shows that a major part of bacterial sulfur is not associated with protein. Furthermore, a high positive correlation between sulfur and oxygen, which has a $\mathrm{CV}_{\mathrm{A}}$ of 0.38 , suggests that much of this sulfur may be associated with oxygen, e.g. as $\mathrm{SO}_{4}^{-2}$. A high relative variation $\left(\mathrm{CV}_{\mathrm{A}}=0.38\right)$ was also found for the $\mathrm{C}$ :volume ratio, a value that, together with the values listed for the same ratio in Table 4 , emphasizes the weak foundation upon which the idea of a universal conversion factor from volume to carbon rests. 


\section{Within-sample variance}

The pooled within-samples coefficient of variation, $\mathrm{CV}_{W}$, has been calculated using Eq. (2) and the values are given in Table 3 . The values are in the range from 0.38 for $\mathrm{O}: \mathrm{C}$ to 0.60 for $\mathrm{S}: \mathrm{C}$. The fact that the $\mathrm{CV}_{\mathrm{W}}$ increases as the ratio decreases (Tables $2 \& 3$ ) suggests that elements that make up a relatively large part of the cells' dry weight, like oxygen, are more constrained in their relative variation than elements that make up a smaller fraction, like sulfur. The C:volume ratio has a $C V_{w}$ of 0.46 , the next highest of the ratios, implying that within a community a considerable variability in water content exists

\section{Contribution from measurement error}

In contrast to $\mathrm{CV}_{\mathrm{A}}, \mathrm{CV}_{\mathrm{W}}$ includes random measurement errors. The within-sample variance for ratios is the sum of 3 relative variances: the relative variance associated with measurement of carbon, the relative variance associated with the other variable (volume, nitrogen, etc.), and finally the inherent relative biological variance.

All ratios include carbon as either divisor or dividend. The major uncertainty in the measurement of carbon is the local variation in the thickness of the supporting film (Norland et al. 1995), implying that small bacteria with low mass thickness (i.e. low mass:area) will have a larger error associated with carbon than larger bacteria. This introduces a relative error with a CV of approximately 0.24 for the mean cell and increases to 0.50 for the smaller ones (e.g. Knebel Vig, 1992). About $10 \%$ of the bacteria in the pooled sample have a carbon mass thickness below the detection limit for carbon ( $10 \mathrm{fg} \mathrm{C} \mathrm{m}^{-2}$ ). This error can be reduced by using a thinner (in terms of carbon) and more even supporting film.

The relative errors associated with nitrogen, oxygen, phosphorus and sulfur are mainly determined by counting statistics (Norland et al. 1995) and are less important. Based on counts under the peaks and in their background, relative errors between 0.03 and 0.15 may bo cstimatcd. An exception to this was suifur in the sample from Lake Kalandsvatnet, a sample comprising small bacteria with a low sulfur content, that had a relative error of 0.3 . The relative errors of the volume estimates have been discussed above. If the estimated contribution due to these 2 sources of relative error is subtracted, the within-sample CVs listed in Table 3 will be reduced by a value between 0.05 (for $\mathrm{S}: \mathrm{C}$ ) and 0.08 (for $\mathrm{O}: \mathrm{C}$ )

It can therefore be concluded that most of the relative variation, e.g. seen as scatter around the regres- sion lines in Figs. $1 \& 2$, is biological heterogeneity and is not an artifact of the measurements. To our knowledge, this is the first time that such an extensive list of within-sample variation, based on measurements of single cells, has been presented.

'Elemental' diversity

The relative variation of the elemental composition within a sample may reflect aspects of the physiological regime in the bacterial community. To obtain an index that expresses this diversity of the elemental composition, we have subjected each sample to a principal components analysis (PCA). PCA will replace the original axes (i.e. measured variables) with new orthogonal axes positioned to maximize the relative variation. This allows us to determine the 'volume' of the hyper-ellipsoid describing the sample. We used the $\mathrm{CV}$ corresponding to the radius in a hyper-sphere with the same 'volume' as a diversity index. This index is a $C V$ that expresses how far from the mean vector the bacteria in the sample are. Vibrio natriegens and Escherichia coli samples had the lowest index, 0.14 and 0.22 , and 0.17 and 0.27 , for stationary and growing states, respectively. The native samples, however, ranged from 0.42 (Raunefjorden, June) to 0.60 (Tvärminne). Native samples had a significantly higher diversity index than $V$. natriegens and $E$. coll, and samples from the stationary phase had a lower index than growing ones for laboratory-grown samples. A significant part of the heterogeneity seen in our data stems from differences in means between species. These indices should, hence, correlate with traditional species-based indices, e.g. the Shannon index. Communities in stable environments tend to have a higher species diversity than communities exposed to seasonal or periodic perturbations (Odum 1971).

\section{Canonical variate analysis}

Canonical variate analysis is a multivariate statistical technique that maximizes the among-group variation relative to total vâriationi. Graphical presentations based on the first 2 canonical axes show the best possible separation of the groups (dispersion). In Fig. 3 sample means of the 10 samples are plotted along with vectors presenting the direction and contribution from the original variables to the dispersion. The first canonical axis, which explains $45 \%$ of the dispersion, may be interpreted as a growth or activity axis separating the growing laboratory cultures from the rest. This separation is mainly brought about by differences in levels of nitrogen, phosphorus or sulfur, probably related to rel- 
atively more protein and nucleic acids in rapidly growing samples. Stationary-phase laboratory cultures are intermediate between growing laboratory cultures and samples of native bacteria. The second canonical axis, which explains $30 \%$ of the dispersion, mainly separates the Knebel Vig (1992) sample with its high levels of oxygen and sulfur from the other samples.

\section{Elemental content and physiological status}

The chemical and, thus, the elemental composition of bacteria depends on growth conditions (Maaloe \& Kjeldgaard 1966, Gräzer-Lampart et al. 1986). Droop (1983) proposed a kinetic model for growth in which he assumes that the growth rate, $\mu$, depends on a internal surplus pool of nutrients and that it is controlled by the nutrients with a cell quota, $Q$, which is relatively closest to its minimum, $Q_{0}$. The Droop model is given by the equation:

$$
\mu=\mu_{\mathrm{m}}\left(1-\frac{Q_{0}}{Q}\right)
$$

where $\mu$ is growth rate and $\mu_{\mathrm{m}}$ is maximal growth rate. Cell quota, $Q$, is expressed either on a per cell basis of element or relative to carbon. $Q_{0}$ is the minimum subsistence quota of the limiting factor, below which no growth occurs. On this basis more comprehensive models have been proposed, e.g. describing the relationship between external substrate concentration, internal cell quota and growth rate under steady state conditions (Martinussen \& Thingstad 1987, Thingstad 1987, Egli 1991). More than one nutrient may be depleted from the medium, but according to this model only a single nutrient may be limiting growth; other nutrients may, however, control the composition of the biomass (Thingstad 1987).

Using chemostats with a range of $\mathrm{N}: \mathrm{C}$ values in the reservoir, Gräzer-Lampart et al. (1986) found that when only carbon was depleted from the medium the $\mathrm{N}: \mathrm{C}$ value in the bacteria was 0.29 , while when only nitrogen was depleted the $\mathrm{N}: \mathrm{C}$ value of the bacteria was 0.18 to 0.20 . Intermediate values were found when both nutrients were depleted. Similar values $(0.31$ and 0.18 , respectively) may be calculated from Thingstad (1987). The sample means for $\mathrm{N}: \mathrm{C}$ values reported in the present paper (Table 2) cover the same range. The above results suggests that the following rule of thumb may be used: if the cellular N:C value is 0.3 or higher, there should be free $\mathrm{N}$ in the environment; if the cellular $\mathrm{N}$ : C value is below 0.2 , the bacterial growth is limited by the $\mathrm{N}$ supply. If we apply this to the present data, the bacteria in the sample from Tvärminne were growth-limited by nitrogen.

A wide range of $Q_{0}$ for phosphorus has been reported (Vadstein 1995); furthermore, it is well known that bacteria store large amounts of phosphorus when it is available (luxury uptake). This implies that it is more difficult to make statements about physiological status based on cellular content for this element. However, if we use a 'typical' $Q_{0} P: C$ value (Vadstein 1995) of 0.031 , and if we assume that the native bacteria had a growth rate well below $\mu_{m}$, we may conclude that the bacteria in our native samples were not P limited. A possible exception might be the sample from Raunefjord, October, which had a P:C value of 0.041. This sample showed a clear growth response following phosphorus addition (Tuomi et al. 1995).

Normally, $\mathrm{N}: \mathrm{C}$ values and especially $\mathrm{P}: \mathrm{C}$ values are high for native bacteria (Table 2). Egli (1991) has shown that slow-growing bacteria have a high carbon demand. This suggests that the supply of carbon will control the bacterial composition, and even often limit their growth.

It has been shown by laboratory studies of bacterial growth that chemical composition and cell size are dependent on growth rate (Maaloe \& Kjeldgaard 1966. Ingraham et al. 1983). In the discussion above we suggest that the relative cellular content of carbon, nitrogen and phosphorus may point to which element is limiting bacterial growth or is controlling bacterial composition. Neither the data for elemental composition presented here nor data from the literature, however, are particularly useful when it comes to estimating activity or growth rates. Our preliminary results, which suggest that the relative oxygen content is lower in stationary state cells than in exponential growing cells, will be pursued. A wider spectrum of elements than those commonly dealt with $(C, N$ and $P$ ) is required to approach the issue of the relationship between elemental composition and bacterial activity.

Acknowledgements. We thank T. Frede Thingstad for critical reading of the manuscript, Pirjo Tuomi for sampling the bacteria from Tvärminne, Jørn $T$ Karlsen for participating in sampling at Lake Kalandsvatnet, Gunnar Bratbak for assistance with the AFM measurements, and Kristen-Olai Fjeldstad at Espegrend marine station for providing the boat used during sampling in Raunefjorden. We are also grateful to Egil $\mathrm{S}$. Erichsen for his contribution to the electron microscopy, done at the Laboratory for Electron Microscopy (LEM) within the Science Faculty of the University of Bergen. The AFM measurements were done at Digital Instrument's application laboratory, Breda, The Netherlands. This work was supported by the Norwegian Research Council's program for marine pollution, contract no. 104330 and MAS2-CT92-0031 (through Frede Thingstad to M.H.).

\section{LITERATURE CITED}

Bakken LR, Olsen RA (1991) DNA content of soil bacteria of different size. Soil Biol Biochem 21:789-793

Bjørnsen PK (1986) Automatic deterination of bacterioplank- 
ton biomass by image analysis. Appl environ Microbiol 51: $1199-1204$

Bratbak G (1985) Bacterial biovolume and biomass estimations. Appl environ Microbıol 49:1488-1493

Bratbak G. Dundas I (1984) Bacterial dry matter content and biomass estimations. Appl environ Microbiol 48:755-757

Cayley S, Lewis BA. Guttman HJ, Record MT Jr (1991) Characterization of the cytoplasm of Escherichia coli K-12 as a function of external osmolarity. Implications for proteinDNA interactions in Vivo. J molec Biol 222:281-300

Cole JJ, Findlay S, Pace ML (1988) Bacterial production in fresh and salt-water ecosystems: a cross-system overview. Mar Ecol Prog Ser 43:1-10

Cuhel RL, Taylor CD, Jannasch HW (1981) Assimilatory sulphur metabolism in marine microorganism: sulphur metabolism, protein synthesis, and growth of Pseudomonas halodurans and Alteromonas luteo-violaceus during unpertubed batch growth. Arch Microbiol 130:8-13

Droop MR (1983) 25 years of algal growth kinetics. Botanica mar 26:99-112

Egli T (1991) On multiple-nutrient-limited growth of microorganisms, with special reference to dual limitation by carbon dnd nitrogen substrates. Antonie van Leeuwenhoek 60:225-234

Fagerbakke KM, Heldal M, Norland S (1991) Variation in elemental content among and within trichomes in Nostoc calcicola 79 WA01 measured by $x$-ray microanalysis. FEMS Microbiol Lett 81:227-232

Finlay BJ, Uhlig $G$ (1981) Calorific and carbon values of marine and freshwater protozoa. Helgoländer Meeresunters 34:401-412

Fry JC (1990) Direct methods and biomass estimation. In: Grigorova R, Norris JR (eds) Methods in microbiology, Vol 22. Academic Press, London, p 41-85

Fry JC, Zia T (1982) Viability of heterotrophic bacteria in freshwater. J gen Microbiol 128:2841-2850

Goldman JC, Caron DA, Dennet MR (1987) Regulation of gross growth efficiency and ammonium regeneration in bacteria by C:N ratio. Limnol Oceanogr 32:1239-1252

Goldman JC, Dennet MR (1991) Ammonium regeneration and carbon utilization by marine bacteria grown on mixed substrates. Mar Biol 109:369-378

Gräzer-Lampart S. Egli T, Hamer G (1986) Growth of Hyphomicrobium ZV620 in the chemostat: regulation of $\mathrm{NH}_{4}{ }^{+}$assimilation enzymes and cellular composition. J gen Microbiol 132: 3337-3347

Heldal M, Norland S. Tumyr O (1985) X-ray microanalytic method for measurement of dry matter and elemental content of individual bacteria. Appl environ Microbiol 50: $1251-1257$

Hobbie JE, Daley RJ, Jasper S (1977) Use of Nucleopore filters for counting bacteria by fluorescence microscopy. Appl environ Microbiol 33:1225-1228

Ingraham JL, Maaloe O, Neidhardt FC (1983) Growth of the

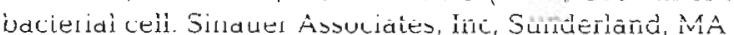

Jordan MJ, Peterson BJ (1978) Sulphate uptake as a measurement of bacterial production. Limnol Oceanogr 23: $146-150$

Jürgens K, Güde H (1990) Incorperation and release of phosphorus by planktonic bacteria and phagotrophic flagellates. Mar Ecol Prog Ser 59:271-274

Kato K (1994) Planktonic bacterial DNA and RNA synthesis from algal extracellular products in a eutrophic lake. FEMS Microbiol Ecol 15:291-298

Kell DB, Ryder HM, Kaprelyants AS, Westerhof HV (1991) Quantifyng heterogeneity: flow cytometry of bacterial cultures. Antonie van Leeuwenhoek 60:145-158
Kiene RP (1990) Dimethyl suphide production from dimethylsulfoniopropionate in coastal seawater samples and bacterlal cultures. Appl environ Microbiol 56:3292-3297

Kiene RP, Bates TS (1990) Biological removal of dimethyl sulphide from seawater. Nature 345:702-705

Kjeldstad B, Heldal M, Nissen H, Evjen K (1991) Changes in polyphosphate composition and localization in Propionebacterium acnes after near-ultraviolet irradiation. Can J Microbiol 37.562-567

Kogure K, Koike I (1987) Particle counter determination of bacterial biomass in seawater. Appl environ Microbiol 53: $274-277$

Kroer N (1994) Relationship between biovolume and carbon and nitrogen content of bacterioplankton. FEMS Microbiol Rev 13:217-224

Ledyard KM, DeLong EF, Dacey JWH (1993) Characterization of a DMSP-degrading bacterial isolate from the Sargasso Sea. Arch Microbiol 160:312-318

Lee S. Fuhrman JA (1987) Relationships between biovolume and biomass of naturally derived marine bacterioplankton. Appl environ Microbiol 53:1298-1303

Lignell R, Kaitala $S$, Kuosa $H$ (1992) Factors controlling phyto- and bacterioplankton in late spring on a salinity gradient in the northern Baltic. Mar Ecol Prog Ser 84 $121-131$

Luria SE (1960) The bacterial protoplasm: composition and organization. In: Gunsalus, IC, Stainer RY (eds) The bacteria, Vol 1. Academic Press, Inc, New York, p 1-34

Maaloe O. Kjeldgaard NO (1966) Control of macromolecular synthesis. WG Benjamin, New York

Malin G, Liss STP, Holligan P, Harbour D (1993) Dimethyl sulphide and dimethylsulphoniopropionate in the north east Atlantic during the summer coccolithophore bloom. Deep Sea Res Part I Oceanogr Res Pap 40:1487-1508

Martinussen I (1991) Roles of heterotrophic bacteria in the cycling of carbon, nitrogen and phosphorus in the marine pelagic environment. Dr scient thesis, University of Bergen

Martinussen I, Thingstad TF (1987) Utilization of N, P and organic $\mathrm{C}$ by heterotrophic bacteria. II. Comparison of experiments and a mathematical model. Mar Ecol Prog Ser 37:285-293

Matrai PA, Keller MD (1994) Total organic sulfur and dimethylsulfoniopropionate in marine phytoplankton: intracellular variations. Mar Biol 119:61-68

Morris DP, Lewis WM Jr (1992) Nutrient limitation of bacterioplankton growth in Lake Dillon, Colorado. Limnol Oceanogr 37:1179-1192

Moyer CL, Morita RY (1989) Effect of growth rate and starvation-survival on the viability and stability of psychrophilic marine bacteria. Appl environ Microbiol 55:2710-2716

Nagata T (1986) Carbon and nitrogen content of natural planktonic bacteria. Appl environ Microbiol 52:28-32

Nissen $H$, Heldal M. Norland S (1987) Growth, elemental composition and formation of polyphosphate bodies in Vibrio natriegens cultures shifted from phosphate-limited to phosphate-pulsed media. Can J Microbiol 33:583-588

Norland S, Fagerbakke KM, Heldal M (1995) Light element analysis of individual bacteria using $X$-ray microanalysis. Appl environ Microbiol 61:1357-1362

Norland S, Heldal M. Tumyr O (1987) On the relation between dry matter and volume in bacteria. Microbiol Ecol 13:95-101

Odum EO (1971) Fundamentals of ecology. WB Saunders Company, Philadelphia

Parnas H (1975) Model for decomposition of organic material by microorganisms. Soil Biol Biochem 7: 161-169 
Preiss J, Romeo I (1989) Physiology, biochemestry and genetics of bacterial glycogen synthesis. Adv microb Physiol 30: $183-238$

Psenner R (1990) From image analysis to chemical analysis of bacteria: a long term study. Limnol Oceanogr 35:234-237

Psenner R, Sommaruga R (1992) Are rapid changes in bacterial biomass caused by shifts from top-down to bottom-up control. Limnol Oceanogr 35:1092-1100

Redfield JL, Ketchum BH, Rickards FA (1963) The infuence of organisms on the composition of seawater. In: Hill MN (ed) The sea. John Wiley \& Sons, New York, p 26-77

Scavia D, Laird GA (1987) Bacterioplankton in Lake Michigan: dynamics, control, and significance to carbon flux Limnol Oceanogr 32:1017-1033

Schut F, deVries EJ, Gottschal JC, Robertson BR, Harder W, Prins RA, Button DK (1993) Isolation of typical marine bacteria by dilution culture: growth, maintenance, and characteristics of isolates under laboratory conditions. Appl environ Microbiol 59:2150-2160

Simon M, Azam F (1989) Protein content and protein synthe. sis rates of planktonic marine bacteria. Mar Ecol Prog Ser 51:201-213

Skjold AC, Jaurez H, Hedgcoth C (1973) Relationships among deoxyribonucleic acide, ribonucleic acid, and spesific transfer ribonucleic acid in Escherichia coli $15 \mathrm{~T}^{-}$at various growth rates. J Bacteriol 115:177-187

Smirnova G, Oktyabrsky O (1995) Betain modulates intracellular thiol and potassium levels in Escherichia coli in medium with high osmolarity and alkaline pH. A.rch Microbiol 163:76-78

Tezukd Y (1990) Bacterial regeneration of ammonium and phosphate as affected by the carbon:nitrogen:phosphorus ratio of organic substrates. Microb Ecol 19:227-238

Responsible Subject Editor: T. H. Blackburn, Aarhus, Denmark
Thingstad TF (1987) Utilization of N, P, and organic C by heterotrophic bacteria. I. Outline of a chemostat theory with a consistent concept of 'maintenance' metabolism. Mar Ecol Prog Ser 35:99-109

Tuomi P, Fagerbakke KM. Bratbak G, Heldal M (1995) Nutritional enrichment of a microbial community: the effects on activity, elemental composition, community structure and virus production. FEMS Microbiol Ecol 16:123-134

Vadstein $O$ (1995) The role of heterotrophic, planktonic bacteria in the cycling of phosphorus in lakes: phosphorus requirements, competitive ability and food web interactions. DPhil thesis, University of Trondheim, Norway

Vadstein O, Jensen A, Olsen Y, Reinertsen H (1988) Growth and phosphorus status of limnetic phytoplankton and bacteria. Limnol Oceanogr 33:489-503

Vadstein O, Olsen Y (1989) Chemical composition and phosphate uptake kinetics of limnetic bacterial communities cultured in chemostates under phosphorus limitation. Limnol Oceanogr 34:939-946

van Veen JA, Paul EA (1979) Conversion of biovolume measurements of soil organisms, growth under various moisture tensions, to biomass and their nutrient content. J Bacteriol 37:686-692

Watson SW, Novitsky TJ, Quinby HL, Valois FW (1977) Determination of bacterial number and biomass in the marine environment. Appl environ Microbiol 33:940-946

Zweifel UL, Hagström $\AA$ (1995) Total counts of marine bacteria include a large fraction of non-nucleotidcontaining bacteria (ghosts). Appl environ Microbiol 61: $2180-2185$

Zweifel UL, Norrman B, Hagström $\AA$ (1993) Consumption of dissolved organic carbon by marine bacteria and demand for inorganic nutrients. Mar Ecol Prog Ser 101:23-32

Manuscript first received: September 15, 1995

Revised version accepted: October 31, 1995 